\title{
CL\&SC editor's special symposium: in the current environment can we afford to marginalize white-collar crime?
}

\author{
Mary Dodge $^{1} \cdot$ Megan Parker ${ }^{1}$
}

Published online: 13 August 2020

(C) Springer Nature B.V. 2020

Scholars, researchers, lawyers, reporters, and other experts in white-collar crime predict increases in corporate and occupational wrongdoing. Amid a global pandemic and demands for social justice, acts of fraud by the powerful elite may go unnoticed or appear less important as societal and individual strains amass. Anomie and enhanced strain may result in deviant adaptations by powerful actors, who operate without restraint as societal structures weaken and change. In fact, criminologist Sally Simpson, predicts increases in offences as pressures, opportunities, and rationalizations further justify wrongdoing. Anecdotal evidence suggests that our current environment is ripe for fraudulent behavior by pharmaceutical companies, politicians, and financial entrepreneurs. Incidents of insider trading, antitrust violations, tax evasion, and price gouging are occurring globally, though data are lacking that can document these trends. Priorities in investigating and prosecuting white-collar crimes are low as designated enforcement agencies are hampered by scarce resources and overwhelming cases. Perhaps, as noted by criminologist Henry Pontell, we may be seeing the "normalization of white-collar crime," though current and future research will assist in avoiding this type of marginalization. Additionally, corporate and occupational crimes will continue to be a primary topic in Crime, Law and Social Change. The following theme-based articles remind us to look back at what we know and continue to stay focused on publishing future empirical research related to white-collar crime.

Mary Dodge and Megan Parker

Publisher's note Springer Nature remains neutral with regard to jurisdictional claims in published maps and institutional affiliations.

Mary Dodge

mary.dodge@ucdenver.edu

1 University of Colorado Denver, Denver, CO 80217, USA 